\title{
Seasonal variation in nutrients, pelagic primary production and grazing in a high-Arctic coastal marine ecosystem, Young Sound, Northeast Greenland
}

\author{
Søren Rysgaard ${ }^{1, *}$, Torkel Gissel Nielsen ${ }^{2}$, Benni Winding Hansen ${ }^{3}$ \\ 'National Environmental Research Institute, Deptartment of Lake and Estuarine Ecology, Vejlsøvej 25, DK-8600 Silkeborg, \\ Denmark \\ ${ }^{2}$ National Environmental Research Institute, Deptartment of Marine Ecology and Microbiology, Frederiksborgvej 399, \\ DK-4000 Roskilde, Denmark \\ ${ }^{3}$ Roskilde University, Deptartment of Life Sciences and Chemistry, DK-4000 Roskilde, Denmark
}

\begin{abstract}
The Young Sound estuary was covered by sea ice for approximately 10 mo during 1996 Investigations of pelagic primary production and estimated grazing were performed during the summer thaw (20 June to 25 August) and in the winter month of February. The phytoplankton community was dominated by diatoms in the surface samples, as well as in the subsurface bloom succeeding the spring bloom. Pelagic primary production was limited by light during sea ice cover. After break-up of the sea ice, silicate initially limited primary production in the surface water due to a well-established pycnocline, and maximum photosynthesis occurred in a subsurface layer at 15 to $20 \mathrm{~m}$ depth. In August, production sank to deeper water layers presumably due to nitrogen limitation. The carbon budget describing the fate of the annual pelagic primary production in Young Sound reveals that the pelagic production of $\sim 10 \mathrm{~g} \mathrm{C} \mathrm{m}^{-2} \mathrm{yr}^{-1}$ was tightly coupled to the grazer community, since total consumption by the grazer community amounted to $10-12 \mathrm{~g} \mathrm{C} \mathrm{m}^{-2} \mathrm{yr}^{-1}$. The classical food web dominated this northeastern Greenlandic fjord, and it was estimated that copepods account for $>80 \%$ of the grazing pressure upon phytoplankton. Based on this study and other values of annual pelagic primary production and sea ice cover found in the literature, we suggest that annual pelagic primary production in the Arctic can be described as proportional to the length of the open water light period. We propose that annual pelagic primary production, and hence secondary production, in a wide range of Arctic marine areas may increase in the future as a consequence of reduction and thinning of sea ice cover due to global warming.
\end{abstract}

KEY WORDS: Primary production - Zooplankton - Grazing Nutrients - Global change · Arctic

\section{INTRODUCTION}

Few investigations of seasonal variation in and fate of pelagic primary production exist from waters around Greenland. The majority of these investigations have been carried out on the west coast of Greenland (Steeman-Nielsen 1958, Petersen 1964, Smidt 1979, Andersen 1981). However, 2 investigations of

-E-mail: sr@dmu.dk seasonal pelagic primary production based on measurements from the productive summer period have been reported from northern Greenland (Jørgen Brønlund Fjord, Andersen 1977a, and Dumbell Bay, Apollonio 1980). From the east coast of Greenland a study of annual phytoplankton counts and zooplankton biomass in Scoresby Sound has been presented (Digby 1953), and, finally, studies of primary and secondary production based on sampling in the productive period have recently been published for the Northeast Water Polynya (Daly 1997, Smith et al. 1997). 
Generally, investigations of pelagic primary production and/or copepod grazing have been based on single sampling occasions at various locations. These investigations cover areas in the Northeast Water Polynya (Hirche et al. 1994, Ashjian et al. 1995, Smith 1995), in Northeast Greenland coastal waters (Rysgaard et al. 1996), further offshore in the Greenland Sea (Smith et al. 1985, Hirche et al. 1991)) and further offshore west of Greenland (Rao \& Platt 1984, and references therein).

It has generally been assumed that in these persistently cold polar waters, temperature limits the rate of photosynthesis. Furthermore, higher primary production rates have been observed in the coastal bays and fjords (see above references). However, a considerable variability in the annual primary production within these coastal waters is seen, and it has been suggested that the annual production may be related to the length of the growth season which, in turn, is governed by the disappearance of snow cover and breaking up of sea ice (Rao \& Platt 1984, Slagstad \& Wassmann 1995). Higher rates of annual production are found on the west coast than on the east coast of Greenland. This difference in production rates may be a result of differences in hydrological conditions. On the west coast, the relatively warm Irminger Current is the main factor controlling the degree of sea ice cover and hence the duration of the productive open water period, whereas the colder East Greenland Current is the corresponding regulating factor on the east coast. Thus, rather than directly controlling pelagic primary production, temperature may act indirectly by affecting sea ice cover and the length of the productive open water period, and consequently the magnitude of annual production.

Studies of world-wide temperature records compiled over the last 100 yr have revealed an average global temperature increase of $0.6^{\circ} \mathrm{C}$ (Hansen \& Lebedeff 1988). Coupled ocean-atmosphere models predict that global warming will cause a further temperature increase of several degrees over the next 50 to $500 \mathrm{yr}$. This temperature increase is predicted to be most pronounced in the Arctic, where it is modeled to be approximately twice the global average (Hansen et al. 1988, Manabe \& Stouffer 1994). Even a warming of 1 to $2{ }^{\circ} \mathrm{C}$ is expected to cause dramatic reduction and thinning of Arctic ice in summer (Manabe et al. 1992, Barry et al. 1993). Furthermore, studies of detailed satellite records have indicated a shortening of the sea ice season, especially in the Sea of Okhotsk, the eastern Arctic Ocean, the Barents Sea, and off the north coast of Russia and the east coast of Greenland (Gloersen \& Campbell 1991, Gloersen et al. 1992, Parkinson 1992). Therefore, if sea ice cover is affected in the future due to global temperature increases, this may be expected to affect the amount of annual primary and, hence, secondary production in Arctic regions.

The aim of the present study was to investigate the seasonal variation in and the fate of pelagic primary production on the East Greenland coast. The objective was to add further to the relatively scarce data existing on both the microbial food web and the classical food chain in Arctic regions. Furthermore, it was our intention to discuss and compare the data obtained with those from other Arctic regions and thus to construct a simple relationship between the length of the productive open water period and annual pelagic primary production.

\section{MATERIALS AND METHODS}

Study site. This investigation was conducted in the Young Sound fjord, at Daneborg in Northeast Greenland, at Sampling Station A (74 $\left.18.58^{\prime} \mathrm{N}, 20^{\circ} 15.04^{\prime} \mathrm{W}\right)$ from 17 June to 25 August 1996. Additional samplings were conducted the following winter during February 1997 (Fig. 1).

Light measurements. On every visit to the station, Secchi depth was measured to identify the euphotic zone. Surface insolation was measured simultaneously using a light sensor (Li-192A, Li-cor Inc., Lincoln, NE, USA).

Temperature and salinity. On every visit to the station, profiles of temperature and salinity were measured at a resolution of $1 \mathrm{~m}$, from the surface to $1 \mathrm{~m}$ above the bottom, using a temperature-salinity probe (Hydrolab Minisonde ${ }^{\circledR}$, Austin, TX, USA). Before measurement the probe was calibrated using standards with a specific conductance as close to the field samples as possible.

Nutrients. The concentration of $\mathrm{NO}_{3}^{-}$was determined on a flow injection analyzer (Alpkem FS3000, Perstorp Analytical Environmental Inc., Wilsonville, OR, USA) using the method described by Grasshoff et al. (1983). Ammonium concentration was determined using the method of Bower \& Holm-Hansen (1980); $\mathrm{PO}_{4}{ }^{3-}$ and Si were determined by standard colorimetric methods as described by Grasshoff et al. (1983). Ammonium, $\mathrm{PO}_{4}{ }^{3-}$ and $\mathrm{Si}$ were analyzed automatically on a robotic sample processor coupled to a spectrophotometer (Tecan RSP-5051 \& Camspec M330, Tecan AG, Hombrechtikon, Switzerland).

Phytoplankton biomass and primary production. Samples of 1 to 21 for chlorophyll a (chl a) measurements were placed in the dark and within $3 \mathrm{~h}$ after collection filtered onto $\mathrm{GF} / \mathrm{F}$ filters, extracted in $96 \%$ ethanol (Jespersen \& Christoffersen 1987) and measured spectrophotometrically (Strickland \& Parsons 1972). Particulate organic carbon was measured by filtering 1 to $2 \mathrm{l}$ onto $45 \mathrm{~mm}$ pre-combusted GF/F filters 

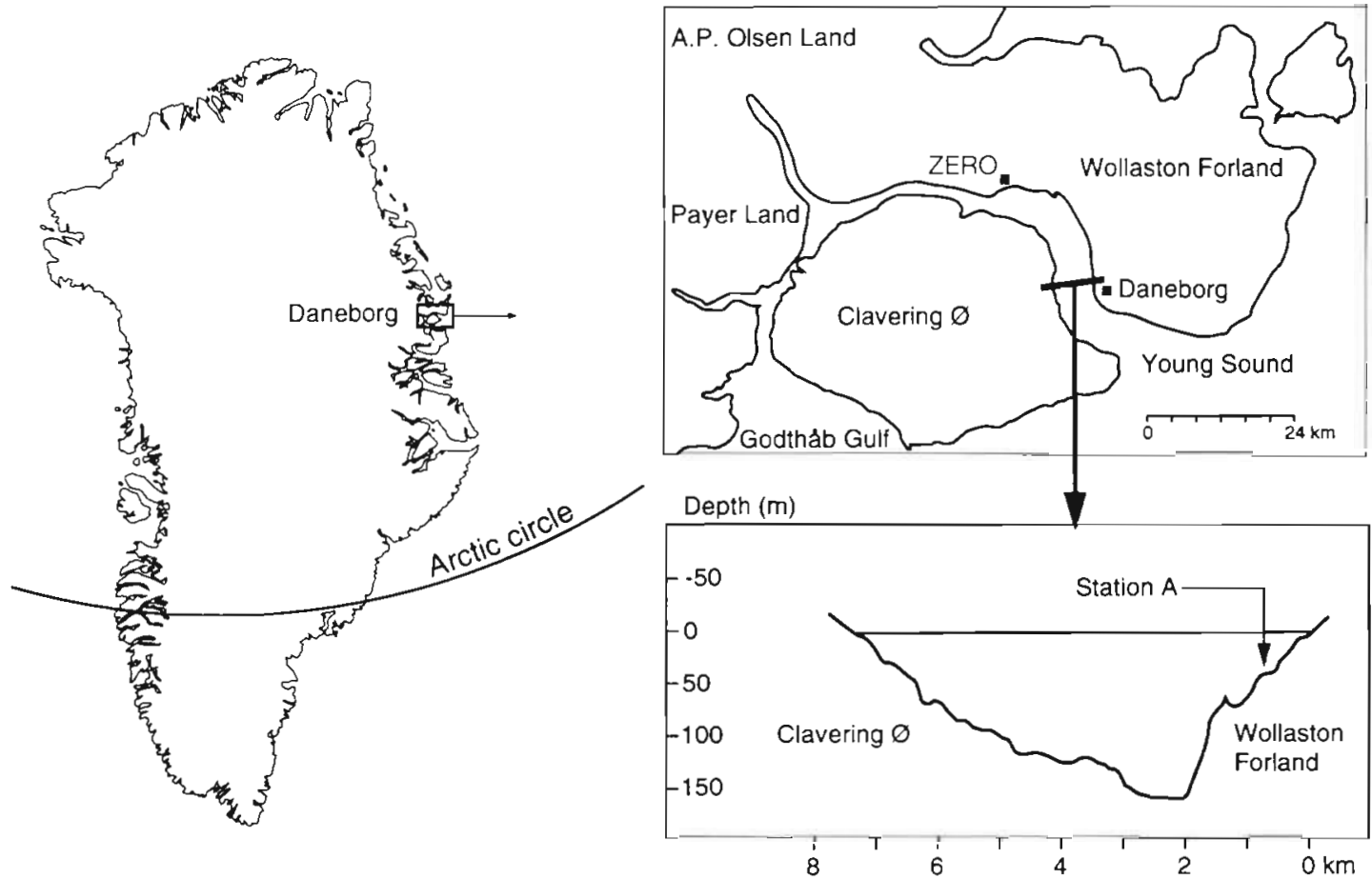

Fig. 1. Location of sampling station in Young Sound near Daneborg, Northeast Greenland. Water depth: $36 \mathrm{~m}$ (ZERO: Zackenberg Ecological Research Operations)

and later analyzed on an elemental analyzer (Roboprep-CN, Europa Scientific, Crewe, UK).

Primary production was measured by the in situ ${ }^{14} \mathrm{C}$ method (Steeman-Nielsen 1952) at noon as well as at midnight. Water samples from various depths were incubated for $2 \mathrm{~h}$ in three $120 \mathrm{ml}$ glass bottles, $2 \mathrm{kept}$ in the light and 1 in the dark, to which $4 \mu \mathrm{Cl} \mathrm{H}^{14} \mathrm{CO}_{3}$ had been added. After incubation the bottles were kept in the dark until filtration which was performed within $1 \mathrm{~h}$. The entire content of each bottle was filtered onto $45 \mathrm{~mm} \mathrm{GF/F} \mathrm{filters.} \mathrm{The} \mathrm{filters} \mathrm{were} \mathrm{transferred} \mathrm{to} \mathrm{scin-}$ tillation vials, inorganic ${ }^{14} \mathrm{C}$ was removed by addition of $200 \mu \mathrm{l}$ of $1 \mathrm{~N} \mathrm{HCl}$ and the samples were frozen until counting. Excess inorganic ${ }^{14} \mathrm{C}$ was removed by directing a flow of air into the vials before addition of scintillation fluid. Total $\mathrm{CO}_{2}$ was measured on several occasions at various depth intervals using a $\mathrm{CO}_{2}$ analyzer (Coulometer CM5012, UIC Inc., Joliet, IL, USA). Daily primary production was calculated by multiplying measured primary production within the incubation period with a light factor (total daily insolation divided by insolation during the incubation period) (Vadstein et al. 1989). Carbon fixation was derived after subtracting the dark fixation values, but without subtracting respiration.

Protozooplankton biomass and species composition. For identification and enumeration of ciliates and dinoflagellates, $250 \mathrm{ml}$ samples were fixed in acid
Lugol's solution ( $2 \%$ final concentration). Samples were kept cold and dark until examination on a Leitz inverted microscope. Depending on the concentration of organisms, 50 or $100 \mathrm{ml}$ water was settled and cells ( $>400$ cells) were counted using the Ütermöhl technique (Ütermöhl 1958). Identification of ciliates to species, group or morphotype was based on Krainer \& Foissner (1990) and Lynn et al. (1988). Dinoflagellates were identified according to Dodge (1985) and to Thomsen (1992). Unidentified species of protozoans were placed in size groups covering size ranges of $10 \mu \mathrm{m}$ estimated spherical diameter (ESD).

Biovolumes of all protozoans were estimated from linear dimensions using appropriate geometric shapes, and converted to biomass using conversion factors of $0.11 \mathrm{pg} \mathrm{C} \mathrm{mm}^{-3}$ for ciliates and athecate dinoflagellates and $0.13 \mathrm{pg} \mathrm{C} \mu \mathrm{m}^{-3}$ for thecate dinoflagellates (Edler 1979). Grazing upon phytoplankton was estimated assuming a clearance of $10^{5}$ body volumes $h^{-1}$ applying a $Q_{10}$ of 2.8 (Hansen et al. 1997).

Copepods. Mesozooplankton was sampled by triplicate vertical hauls from bottom to surface with a WP-2 net $(70 \mu \mathrm{m}$ mesh size) equipped with a non-filtering cod-end and a flowmeter (Digital Model 438110 , HydroBios, Kiel) on 4 occasions. The zooplankton samples were immediately preserved in $2 \%$ buffered formalin. In the laboratory, the zooplankton samples were processed and identified according to the protocol of 


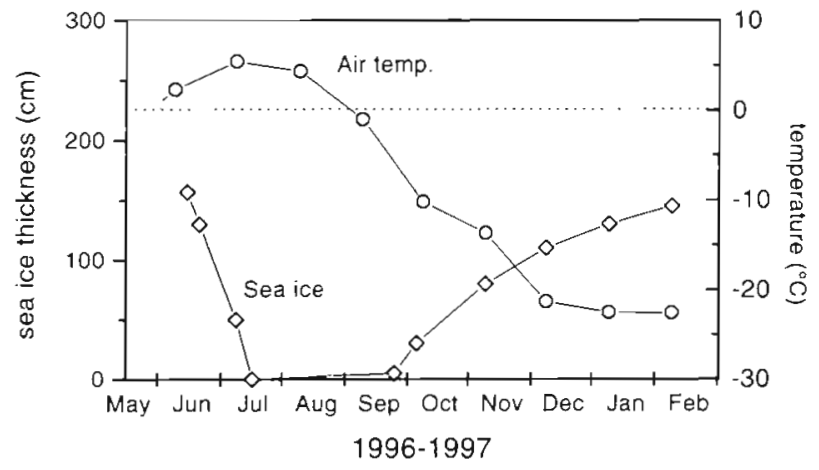

Fig. 2. Air temperature and sea ice thickness at the sampling station during the investigation period

Nielsen \& Hansen (1995). The mesozooplankton community grazing ( $I$ ) was estimated by 2 methods: (1) the temperature-dependent copepod production $(P)$ method, where $I=B \times 0.045 \mathrm{e}^{0.111 T}$, based upon daily standing stock $(B)$ and ambient temperature $(T$; mean temperature of the entire water column) (Huntley \& Lopez 1992) assuming a $33 \%$ growth efficiency $I=3 \times$ $P$ (Peterson 1988); and (2) after Hansen et al. (1997) assuming maximum clearance $\left(C_{\max }\right)$, due to the relatively low phytoplankton concentration, $\log C_{\max } \times \log a$ $-0.23 \log P_{\text {vol }}$, where -0.23 is a scaling factor between predator size $\left(P_{\mathrm{vol}}\right)$ and maximum clearance. The mesozooplankton community grazing $(I)$ equals $C_{\max } \times$

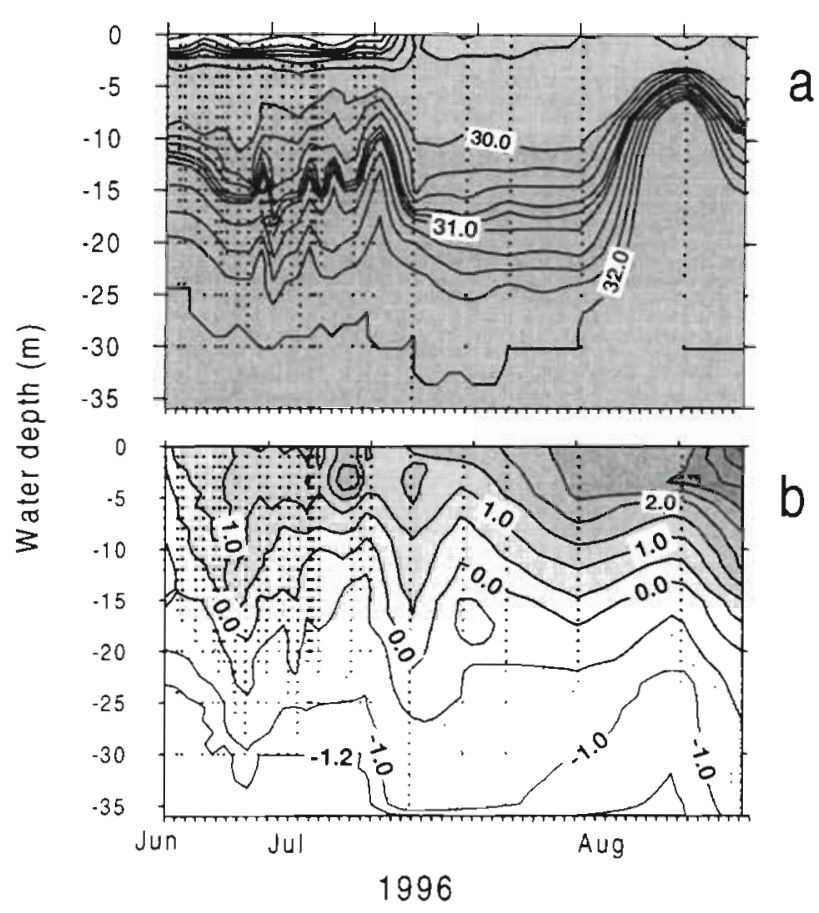

Fig. 3. Vertical distribution of (a) salinity and (b) temperature in the water column of Young Sound. Dots indicate the resolution of measurements phytoplankton concentration. The community grazing values estimated from Hansen et al. (1997) were temperature corrected by $Q_{10}=2.8$.

\section{RESULTS}

\section{Hydrography and distribution of nutrients}

The present study covered periods of both sea ice cover and open water in Young Sound. The sea ice broke in the middle of July, after which it drifted within the fjord for a couple of weeks before it was exported to the Greenland Sea. However, on several occasions throughout the open water period, pack ice entered the Sound from the Greenland Sea. Regular sea ice was well established again by early October. The surface insolation in the area described a bell-shaped curve with a maximum of $1200 \mu \mathrm{mol}$ photons $\mathrm{m}^{-2} \mathrm{~s}^{-1}$, giving rise to a maximum Secchi depth of $15 \mathrm{~m}$. The sea ice thickness was approximately $1.5 \mathrm{~m}$ with $0.4 \mathrm{~m}$ snow cover in the beginning of the study period, it then decreased gradually; open water was present in midJuly and prevailed until late September (Fig. 2).

Until the sea ice broke up, a freshwater lens was present in the upper $2 \mathrm{~m}$ just below the sea ice due to melt water run-off from Clavering Island, A.P. Olsens Land, Payer Land and Wollaston Forland, and from the sea ice itself. Immediately following the break-up of the ice the fresh water was mixed into the surface layer. A pycnocline was found in the water column at 15 to $20 \mathrm{~m}$ depth, except for a period in August when a storm. moved the pycnocline to $5-10 \mathrm{~m}$, most probably due to displacement of less saline surface water to the Greenland Sea by incoming, higher salinity bottom water (Fig. 3a)

After the sea ice disappeared, the temperature of the surface layer increased to about $5^{\circ} \mathrm{C}$, whereas the bottom water temperature was rather constant at $-1^{\circ} \mathrm{C}$ throughout the investigation (Fig. 3b).

Ammonium was present in concentrations up to $0.5 \mu \mathrm{M}$ in the water column during sea ice cover in June and July; and later in the open water period it dropped below the detection limit $(0.2 \mu \mathrm{M})$ due to phytoplankton uptake (Fig. 4a). Furthermore, relatively low concentrations of ammonium were observed in the freshwater lens, presumably due to dilution by melt water from the surrounding land and from the sea ice itself.

A vertical concentration gradient of $\mathrm{NO}_{3}{ }^{-}$was observed in the water column (Fig, 4b). Concentrations $>3 \mu \mathrm{M}$ were measured in the bottom water and concentrations $<0.5 \mu \mathrm{M}$ were found immediately below the sea ice, presumably due to dilution by melt water. Later in the open water period, the zone in the water 
column with low $\mathrm{NO}_{3}^{-}$concentration increased due to phytoplankton uptake

Throughout the summer thaw, phosphorus was present in excess below the freshwater plume, here the $\mathrm{PO}_{4}{ }^{3-}$ concentration increased from 0.4 to $0.8 \mu \mathrm{M}$ just above the bottom (Fig. 4c).

Silicate had a bimodal vertical distribution with relatively high values $(2$ to $5 \mu \mathrm{M})$ in the fresh surface water during ice cover (Fig. 4d). In the middle of the water column, down through the pycnocline associated with the peak biomass of phytoplankton, low concentrations $(<0.5 \mu \mathrm{M})$ were measured. Finally, in the bottom water, concentrations of silicate increased to values of 3 to $6 \mu \mathrm{M}$ just above the bottom.

\section{Phytoplankton composition, biomass and production}

The phytoplankton community was dominated by diatoms. Chl a was located in a subsurface peak (15 to $20 \mathrm{~m}$ ) before the sea ice cover melted $\left(1.3 \mu \mathrm{g} \mathrm{l}^{-1}\right)$ and increased in concentration during the open water period $\left(1.8 \mathrm{\mu g} \mathrm{l}^{-1}\right)$ in the same depth stratum. In the surface water, chl a concentrations of 0.5 to $1 \mu \mathrm{g} \mathrm{I}^{-1}$ were observed throughout the study period (Fig. 5a). The depth-integrated biomass of phytoplankton showed peak increase to $2.8 \mathrm{~g} \mathrm{C} \mathrm{m}^{-2}$ following break up of the sea ice, after which it decreased to $1.2 \mathrm{~g} \mathrm{C} \mathrm{m}^{-2}$ in midAugust and to negligible levels in February (Fig. 6a).

Primary production of the phytoplankton community was initially low during sea ice cover, although chl a was present in the water column. However, primary production increased steeply when sea ice broke and reached up to $12 \mathrm{mg} \mathrm{C} \mathrm{m}^{-3} \mathrm{~d}^{-1}$ in a subsurface bloom at 15 to $20 \mathrm{~m}$ depth. The bloom lasted until August when primary production began to sink to even greater water depths (Fig. 5b).

\section{Ciliates and heterotrophic dinoflagellates}

Ciliates and heterotrophic dinoflagellates contributed equally to the protozooplankton biomass throughout the investigation period (Fig. 5c,d). Both ciliates and heterotrophic dinoflagellates were present in high numbers in the surface waters during ice cover, and following break-up of the sea ice they concentrated in the subsurface water layer together with their prey, phytoplankton. However, heterotrophic dinoflagellates were distributed closer to the surface than ciliates.

The depth-integrated biomass for ciliates and heterotrophic dinoflagellates increased from 70 and $50 \mathrm{mg} \mathrm{C} \mathrm{m}{ }^{-2}$, respectively, on the initial sampling occasion to peak biomasses of 143 and $70 \mathrm{mg} \mathrm{C} \mathrm{m}^{-2}$, respec-

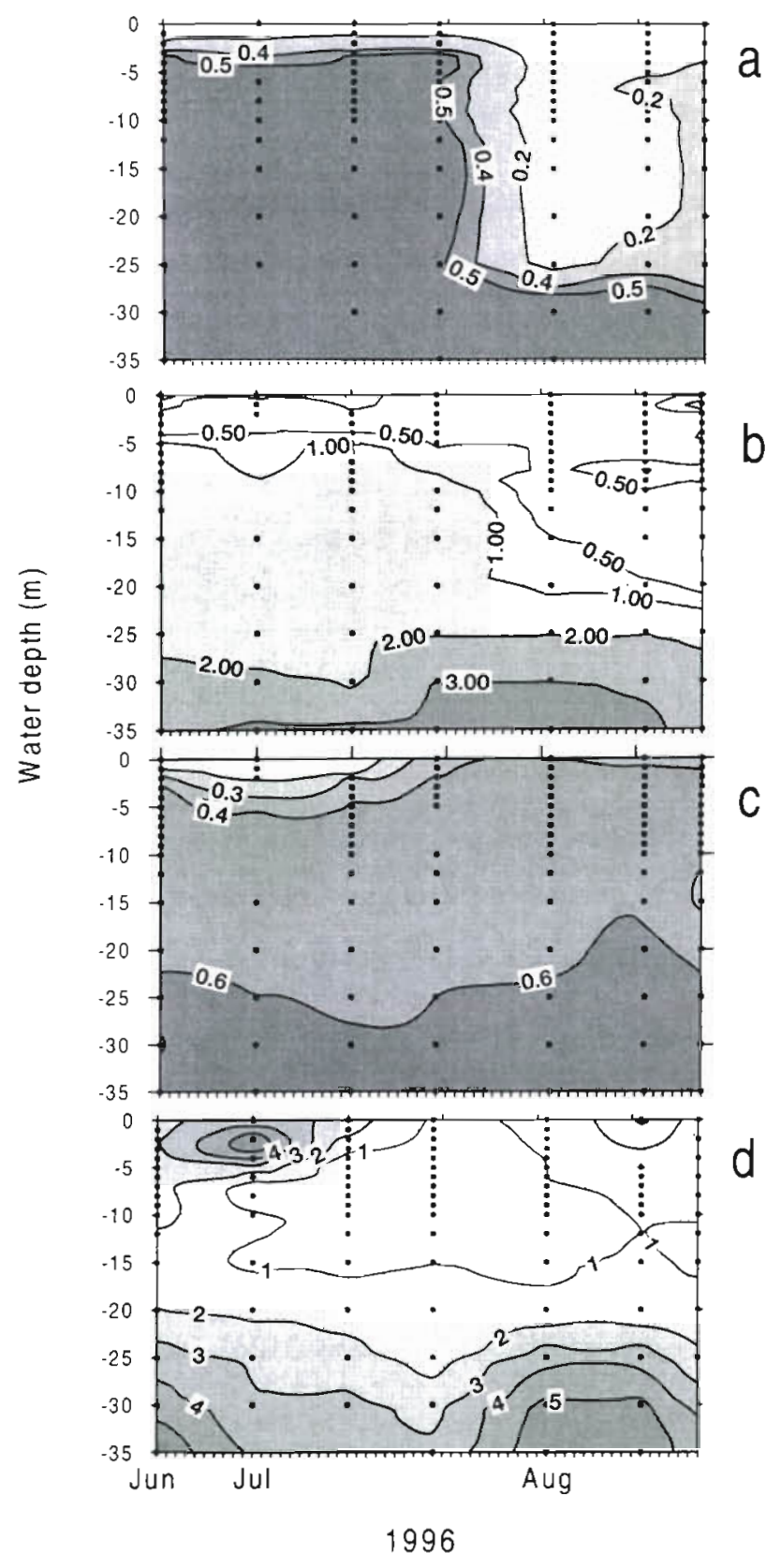

Fig. 4. Vertical distribution of (a) ammonium, (b) nitrate + nitrite, (c) phosphorus and (d) silicate. All concentrations are $\mu \mathrm{M}$ values, and dots indicate the resolution of measurements

tively, following the break-up of the sea ice (Fig. 6b,c). Then, in mid-August the integrated biomass decreased rapidly to 20 and $22 \mathrm{mg} \mathrm{C} \mathrm{m}{ }^{-2}$ for ciliates and heterotrophic dinoflagellates, respectively. During winter very low biomasses were observed for both ciliates and heterotrophic dinoflagellates (see Table 2).

The ciliate community was dominated by naked oligotrich ciliates (Strombidium and Strobilidium) and predaceous forms (Balanion and Didinium), except on the first sampling day when the surface layer was com- 


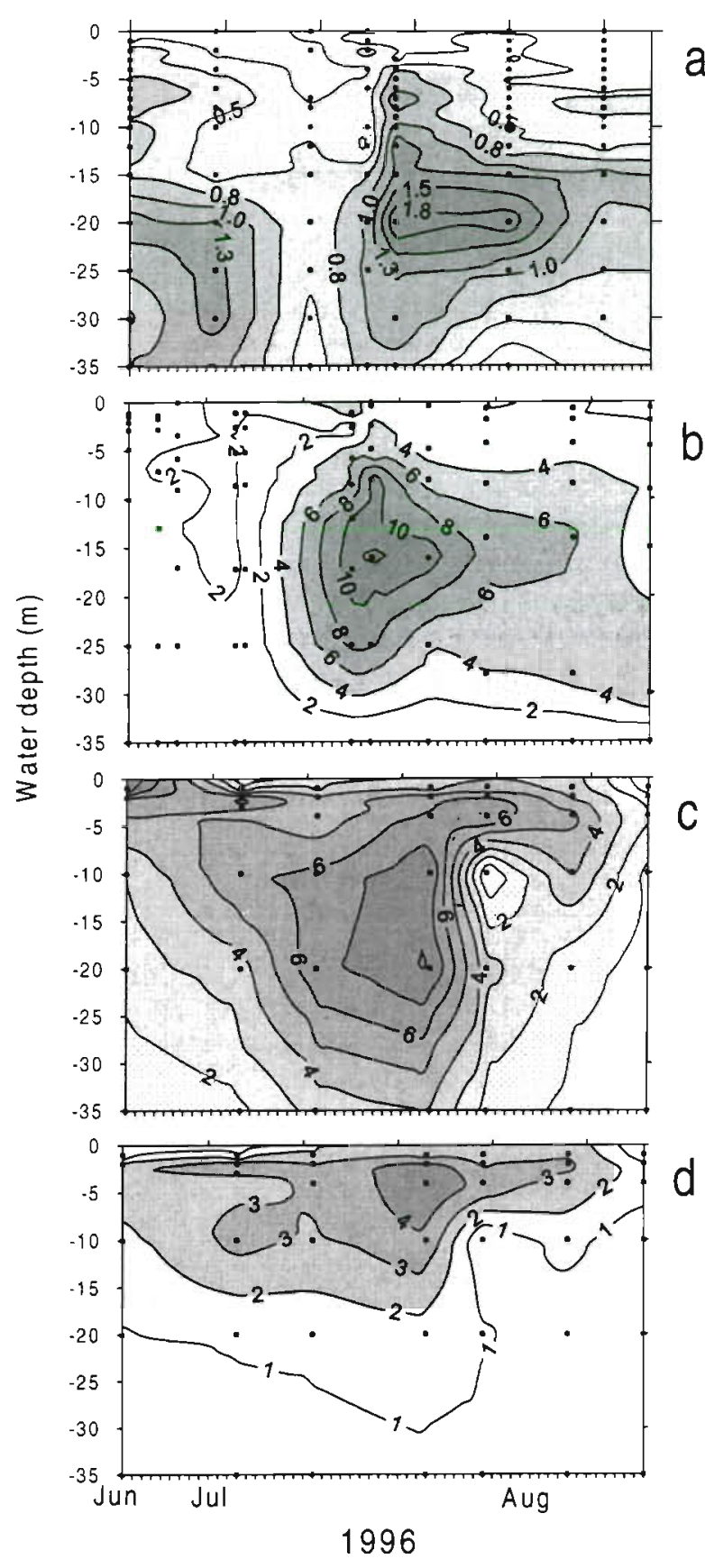

Fig. 5. Vertical distribution of (a) chl $a_{1} \mu \mathrm{g} \mathrm{l}^{-1}$; (b) pelagic primary production, $\mu \mathrm{g} \mathrm{C} \mathrm{Cl}^{-1} \mathrm{~d}^{-1}$; (c) ciliates, $\mu \mathrm{g} \mathrm{Cl}^{-1}$; and (d) heterotrophic dinoflagellates, $\mu \mathrm{g} \mathrm{Cl}^{-1}$. Dots as in Fig. 3

posed of Euplotes spp., presumably a part of the biota associated with sea ice. This assumption is supported by the winter sample (13 February) when Euplotes spp. again dominated the ciliate biomass just below the sea ice. The vertical distribution of the ciliate community was similar to that of phytoplankton with maximum occurrence in the middle of the water column in mid-July (Fig. 5a,c).

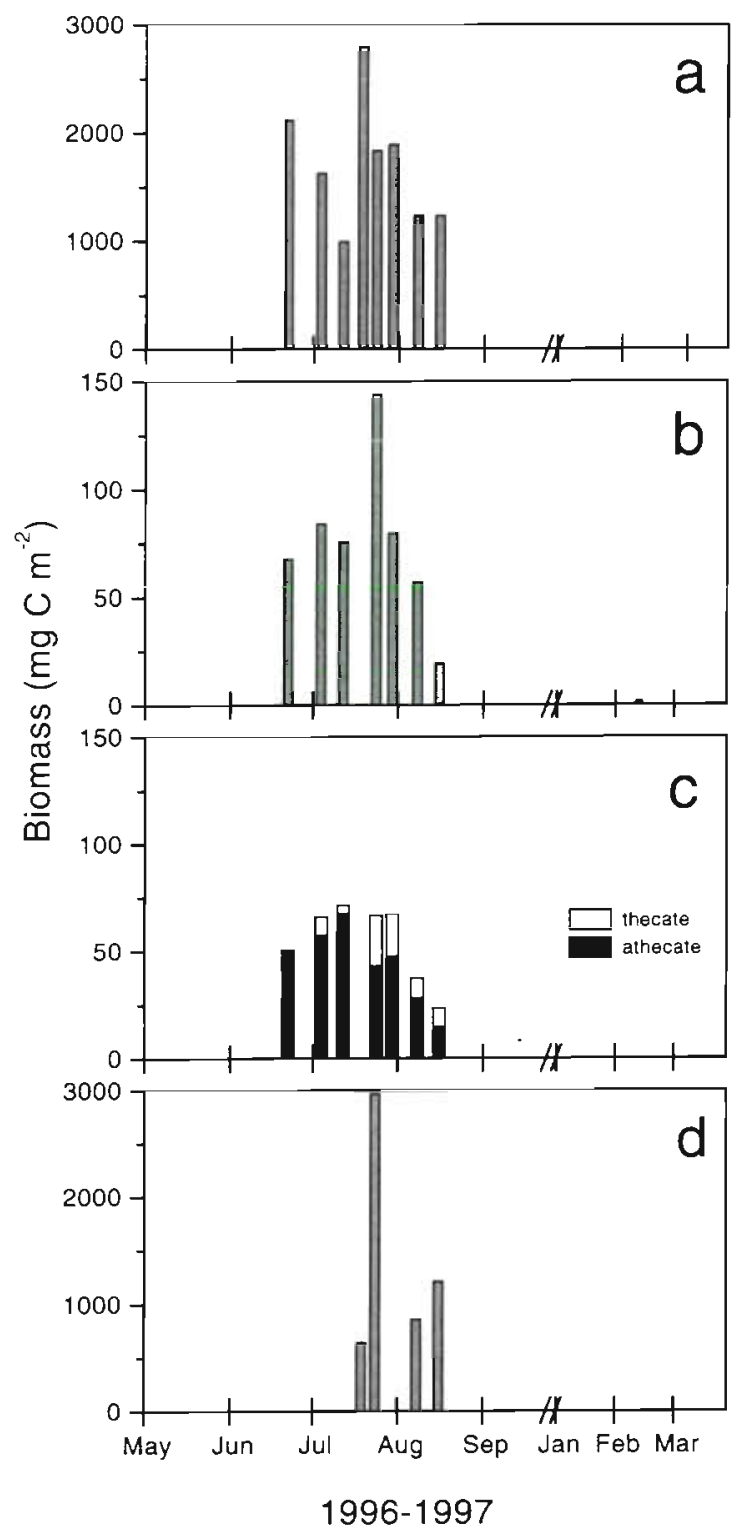

Fig. 6. Integrated biomass of (a) phytoplankton, (b) ciliates, (c) heterotrophic dinoflagellates and (d) copepods in the water column of Young Sound

The dinoflagellate community was dominated by large naked species (Gyrodinium spirale) and other athecate forms $>40 \mu \mathrm{m}$ ESD. The highest biomass of heterotrophic dinoflagellates was observed in the upper $10 \mathrm{~m}$ of the water column above the primary pycnocline (Fig. 5d).

\section{Mesozooplankton}

The mesozooplankton community in Young Sound was composed of Calanus spp., Pseudocalanus spp., Microcalanus spp., Oithona spp., Onchaea spp., and 
Table 1. Mean $\pm \mathrm{SD}$ biomass $\left(\mathrm{mg} \mathrm{C} \mathrm{m}^{-3}\right.$ ) of triplicate samples of mesozooplankton and estimated commnity copepod production and grazing in Young Sound, 1996

\begin{tabular}{|c|c|c|c|c|}
\hline & 18 July & 24 July & 8 August & 16 August \\
\hline \multicolumn{5}{|l|}{ Copepods } \\
\hline Calanus finmarchicus & $3.29 \pm 5.58$ & $5.03 \pm 2.27$ & $0.52 \pm 0.33$ & $2.38 \pm 4.03$ \\
\hline Calanus glacialis & $6.10 \pm 5.02$ & $51.13 \pm 16.33$ & $12.96 \pm 11.54$ & $18.46 \pm 4.38$ \\
\hline Calanus hyperboreus & $4.60 \pm 2.26$ & $20.34 \pm 6.44$ & $5.77 \pm 5.51$ & $3.70 \pm 0.96$ \\
\hline Pseudocalanus spp. & $0.97=1.25$ & $0.78 \pm 0.59$ & $2.06 \pm 1.37$ & $2.06 \pm 0.82$ \\
\hline Microcalanus spp. & $0.04=0.03$ & $0.04 \pm 0.03$ & $0.03 \pm 0.02$ & $0.05 \pm 0.03$ \\
\hline Oithona spp. & $0.19 \pm 0.05$ & $0.46 \pm 0.06$ & $0.23 \pm 0.23$ & $1.07 \pm 0.10$ \\
\hline Onchaea spp. & $0.12 \pm 0.04$ & $0.19 \pm 0.08$ & $0.14 \pm 0.11$ & $0.92 \pm 0.26$ \\
\hline Other copepodites & $0.02 \pm 0.03$ & $0.04 \pm 0.06$ & $0.01 \pm 0.01$ & $0.03 \pm 0.03$ \\
\hline Nauplii & $3.16 \pm 1.77$ & $6.80 \pm 1.14$ & $2.88 \pm 2.21$ & $5.53 \pm 1.22$ \\
\hline Total copepods & $18.48 \pm 8.13$ & $84.79 \pm 17.75$ & $24.60 \pm 13.04$ & $34.19 \pm 6.21$ \\
\hline Area biomass $\left(\mathrm{mg} \mathrm{C} \mathrm{m}^{-2}\right)$ & 646 & 2968 & 865 & 1197 \\
\hline \multicolumn{5}{|l|}{ Other groups } \\
\hline Copepod eggs & $0.41 \pm 0.43$ & $0.69 \pm 0.11$ & $0.15 \pm 0.08$ & $0.37 \pm 0.18$ \\
\hline Invertebrate larvae & $0.07 \pm 0.12$ & $0.02 \pm 0.04$ & 0 & $0.02 \pm 0.02$ \\
\hline Appendicularia & $1.00 \pm 0.45$ & $1.33 \pm 0.51$ & $1.86 \pm 2.42$ & $2.79 \pm 1.28$ \\
\hline \multicolumn{5}{|c|}{ Copepod production, growth and grazing estimates } \\
\hline Production (mg C m$\left.{ }^{-2} \mathrm{~d}^{-1}\right)$ & 26.5 & 133.5 & 38.9 & $61.5^{\mathrm{a}}$ \\
\hline Specific growth rate $\left(\mathrm{d}^{-1}\right)$ & 0.041 & 0.045 & 0.045 & $0.051^{\mathrm{a}}$ \\
\hline \multirow[t]{2}{*}{ Community grazing ( $\mathrm{mg} \mathrm{C} \mathrm{Cm}^{-2} \mathrm{~d}^{-3}$ ) } & 79.5 & 400.5 & 116.8 & $184.6^{\mathrm{a}}$ \\
\hline & 132.4 & 388.8 & 76.0 & $119.7^{6}$ \\
\hline Mean water column temperature $\left({ }^{\circ} \mathrm{C}\right)$ & 0.38 & 0.10 & 0.10 & 1.30 \\
\hline $\begin{array}{l}\text { aModel } 1 \text { (Huntley \& Lopez 1992) } \\
\text { bModel } 2 \text { (Hansen et al. 1997) }\end{array}$ & & & & \\
\hline
\end{tabular}

some harpacticoid copepods. Additionally, a few larvae from benthic invertebrates, Bivalvia, Gastropoda and Polychaeta, were identified as well as appendicularians, represented by Fritellaria sp. and Oikopleura $\mathrm{sp}$. The community in general was numerically dominated by copepods. Unidentified calanoid nauplii, most likely Calanus spp., was the most abundant group, with numbers up to $8000 \mathrm{~m}^{-3}$, followed by copepodites of the cyclopoids Onchaed spp. and Oithona spp., and then Calanus glacialis and Pseudocalanus spp. In terms of biomass the 3 Calanus spp., $C$. glacialis, $C$. hyperboreus and $C$. finmarchicus, dominated the standing stock with 70 to $90 \%$ of the total copepod biomass, followed by the calanoid nauplii, accounting for 10 to $17 \%$. The appendicularians were abundant, up to $2000 \mathrm{~m}^{-3}$, but their biomass was insignificant in comparison with copepods. The total mesozooplankton biomass fluctuated, with $20 \mathrm{mg} \mathrm{C}$ $\mathrm{m}^{-3}$ on 18 July, increasing to $85 \mathrm{mg} \mathrm{C} \mathrm{m}^{-3}$ on 24 July, after which it declined during August to 25 and $34 \mathrm{mg}$ $\mathrm{C} \mathrm{m}^{-3}$ (Table 1 ). The relative biomass composition of the different species at the 4 samplings was similar. A total mean of the copepod biomass during the entire period was $40.5 \mathrm{mg} \mathrm{C} \mathrm{m}^{-3}$.
The triplicate net tow samplings performed on every occasion gave an 18 to $52 \%$ standard deviation of the copepod biomass (Table 1), typically increasing with individual body size among the species. This variability did not differ between samplings, however, and therefore we consider the biomass estimates to be accurately determined. The specific community production of copepods calculated by Model 1 from mean water column temperatures $(0.38,0.1,0.1$, $1.3^{\circ} \mathrm{C}$ ) was 0.041 to $0.051 \mathrm{~d}^{-1}$ giving rise to a community grazing impact in the range of 80 to $400 \mathrm{mg} \mathrm{C}$ $\mathrm{m}^{-2} \mathrm{~d}^{-1}$, in accordance with Model 2 community grazing values.

\section{Winter sampling}

The sampling performed 6 February, 1997 revealed a well-mixed water column of $-1.8^{\circ} \mathrm{C}$ and $32.2 \mathrm{psu}$ below $1.5 \mathrm{~m}$ ice cover with $40 \mathrm{~cm}$ snow cover (Table 2). Maximum surface irradiance during diurnal cycles in early February was $13 \mu \mathrm{mol}$ photons $\mathrm{m}^{-2} \mathrm{~s}^{-1}$, and no light could be detected below the sea ice (<1 $\mu \mathrm{mol}$ photons $\mathrm{m}^{-2} \mathrm{~s}^{-1}$ ). In contrast to the summer 
Table 2. Winter values of pelagic parameters from Young Sound, 6 February 1997

\begin{tabular}{|c|c|c|}
\hline & Surface water & Bottom water \\
\hline Salinity (psu) & 32.2 & 32.2 \\
\hline Temperature $\left({ }^{\circ} \mathrm{C}\right)$ & -1.9 & -1.8 \\
\hline $\mathrm{NH}_{4}^{+}(\mu \mathrm{M})$ & 1.3 & 1.3 \\
\hline $\mathrm{NO}_{3}^{-}(\mu \mathrm{M})$ & 2.9 & 3.0 \\
\hline $\mathrm{PO}_{4}^{3-}(\mu \mathrm{M})$ & 1.2 & 1.2 \\
\hline $\mathrm{Si}(\mu \mathrm{M})$ & 6.0 & 6.1 \\
\hline Light ( $\mu \mathrm{mol}$ photons $\mathrm{m}^{-2} \mathrm{~s}^{-1}$ ) & $<1$ & $<1$ \\
\hline $\mathrm{Chl} a\left(\mu \mathrm{gl}^{-1}\right)$ & $<0.05$ & - \\
\hline Prim. prod. $\left(\mathrm{mg} \mathrm{C} \mathrm{m}^{-3} \mathrm{~d}^{-1}\right)$ & 0 & 0 \\
\hline $\mathrm{H}$ dino $\left(\mathrm{mg} \mathrm{C}^{-3}\right)$ & 0 & 0.003 \\
\hline Ciliates ( $\mathrm{mg} \mathrm{C} \mathrm{m}^{-3}$ ) & 0.23 & 0.04 \\
\hline Copepods (mg C m${ }^{-3}$ ) & $0^{\mathrm{a}}$ & 0 \\
\hline
\end{tabular}

period, winter concentrations of $\mathrm{NH}_{4}{ }^{+}, \mathrm{NO}_{3}{ }^{-}, \mathrm{PO}_{4}{ }^{3-}$ and $\mathrm{Si}$ showed little variation because of the wellmixed water column (Table 2). The phytoplankton biomass was negligible, and no primary production was detected.

Due to difficulties with drilling an adequate hole in the sea ice and due to high wind velocities, it was not possible to obtain a net tow with the WP-2 net. Therefore, drawing a net tow from bottom to surface using a $0.25 \mathrm{~m}$ diameter plankton net with a $20 \mu \mathrm{m}$ mesh size was the only option. However, no mesozooplankton at all was observed in these samples.

\section{DISCUSSION}

\section{Hydrography and regulation of primary production}

The hydrography within Young Sound is strongly influenced by sea ice and input of fresh water. Large amounts of melt water enter the fjord during the summer thaw from the surrounding land and from the sea ice itself. A freshwater lens just below the sea ice persisted until the sea ice broke, after which it was mixed into the surface layers of the water column. Saline polar water enters the fjord mainly from the Greenland Sea between Wollaston Forland and Clavering Island due to the East Greenland Current and tidal exchange. The combined effect of freshwater input to the surface layers of the water column and higher salinity polar water entering the Sound from the Greenland Sea created a stable pycnocline in the middle of the water column (Fig. 3). Thus, the strong stratification during the investigated summer period effectively sealed the nutrients in the deep water layers (Fig. 4). The nutrient concentration levels measured in the water column of Young Sound were similar to observations from the adjacent Greenland Sea (Smith et al. 1985, Spies et al. 1988, Lara et al. 1994, Smith 1995).

During the period of sea ice cover the interception of light by the sea ice and snow cover created poor light conditions in the water column for pelagic primary production. However, following the break-up of the ice the immediate increase in light penetration to the water column caused a steep increase in pelagic primary production and consequently chl a concentrations (Fig. 5a,b). Like nutrient levels, chl a levels measured within the Sound were similar to observations from the adjacent Greenland Sea (Smith et al. 1985, Spies et al. 1988, Lara et a.l. 1994, Weslawski et al. 1997).

The phytoplankton community was dominated by diatoms in the surface samples as well as in the subsurface bloom. Since primary production during the period of ice cover was low, the chl $a$ in the water column before the break-up of ice may originate from the algal community associated with sea ice. Due to a high uptake of silicate by the diatoms and due to the pycnocline effectively sealing the water column, the concentration of silicate above the subsurface layer was reduced to $<0.5 \mu \mathrm{M}$ (Fig. $4 \mathrm{~d}$ ). Silicate concentrations of $<2 \mu \mathrm{M}$ have generally been shown to limit primary production of diatoms (Egge \& Aksnes 1992). According to Liebig's classical way of evaluating nutrient limitation through comparison of observed $P: N$ and Si:N concentrations with the Redfield ratio, 15Si:16 N:1P (by atoms), silicate was initially the main nutrient limiting primary production since the Si:N ratio was $\ll 1$ (Fig. 4). Phosphorus was present in excess throughout the investigation period and therefore did not limit primary production, in accordance with observations from Arctic waters in general (e.g. Harrison \& Cota 1991). In August, both nitrate and ammonium were depleted below the detection limit $(<0.2 \mu \mathrm{M})$ in the surface water, thereby limiting primary production, which may explain why the diatom bloom descended to even deeper water layers. It was shown in a parallel study (Rysgaard et al. 1998) that nutrients $\left(\mathrm{NO}_{3}{ }^{-}, \mathrm{NH}_{4}{ }^{+}\right.$, urea, $\left.\mathrm{PO}_{4}{ }^{3-}, \mathrm{Si}\right)$ were released from the sediment to the overlying water throughout the year, due to mineralization in the sediment. Furthermore, mineralization in the sediment responded immediately after sedimentation of organic matter when sea ice broke, and nutrients were rapidly returned to the water column, proving the coupling between sea bed and water column in the Sound to be effective. The bacterial mineralization in the sediment explains the relatively high concentrations of nutrients in the bottom layers of the water column. A similar regulation of pelagic primary production by nutrients has also been observed in other Arctic studies (Nielsen \& Hansen 1995). 


\section{The grazer community}

The species composition and the overall biomass pattern of copepods resemble results reported by Digby (1953) from Scoresby Sound, East Greenland. The obtained daily specific growth rate of the population based upon Model 1 was 0.04 to 0.05 , which is equal to that reported for the same species from other Arctic areas (e.g. Runge 1985. Hirche \& Bohrer 1987 , Nielsen \& Hansen 1995, Hansen et al. 1996). Since estimated grazing is calculated from the specific growth rates, our community grazing estimates are considered to be within a reasonable range.

Few investigations are available on the role of protozooplankton in Arctic food webs, even though their importance has been demonstrated in low latitude ecosystems over the past 2 decades. Even fewer studies consider the 2 main components of the protozooplankton simultaneously: the ciliates and the heterotrophic dinoflagellates. According to size both groups belong to the microplankton, but their functional biology is very different; planktonic ciliates prey on the nanofraction, while the dinoflagellates prefer a prey size similar to their own (Hansen et al. 1994). In the present investigation, ciliates and heterotrophic dinoflagellates contributed equally to the protozooplankton biomass (Fig. 6), and in general the vertical and seasonal distributions of protozooplankton were similar to those of the phytoplankton (Figs. $5 \& 6$ ). The species composition and relative contribution of the 2 groups of protozoans are comparable with observations from the Disko Bay on the west coast of Greenland (Nielsen \& Hansen 1995, Levinsen et al. 1998). However, the absolute biomass of ciliates and heterotrophic dinoflagellates in Young Sound is lower compared with the more productive Disko Bay, where maximum integrated summer biomass values of 750 and $1000 \mathrm{mg} \mathrm{C} \mathrm{m}{ }^{-2}$ have been obtained for ciliates and heterotrophic dinoflagellates, respectively.

\section{Annual pelagic primary production}

An annual estimate of pelagic primary production was made based on 11 direct measurements during the productive summer season and 1 during the unproductive winter period. On arrival at Young Sound, 20 June, the Sound was covered with $\sim 1.5 \mathrm{~m}$ sea ice and $0.4 \mathrm{~m}$ snow. Although chl a was initially present in the water column, ${ }^{14} \mathrm{C}$ measurements revealed only low rates of primary production due to the unfavorable light conditions in the water column as a result of the sea ice and snow cover during winter; these conditions prevailed until the sea ice disappeared in July (Figs. $2 \& 5 a, b$ ). The chl a observed in the water column during sea ice

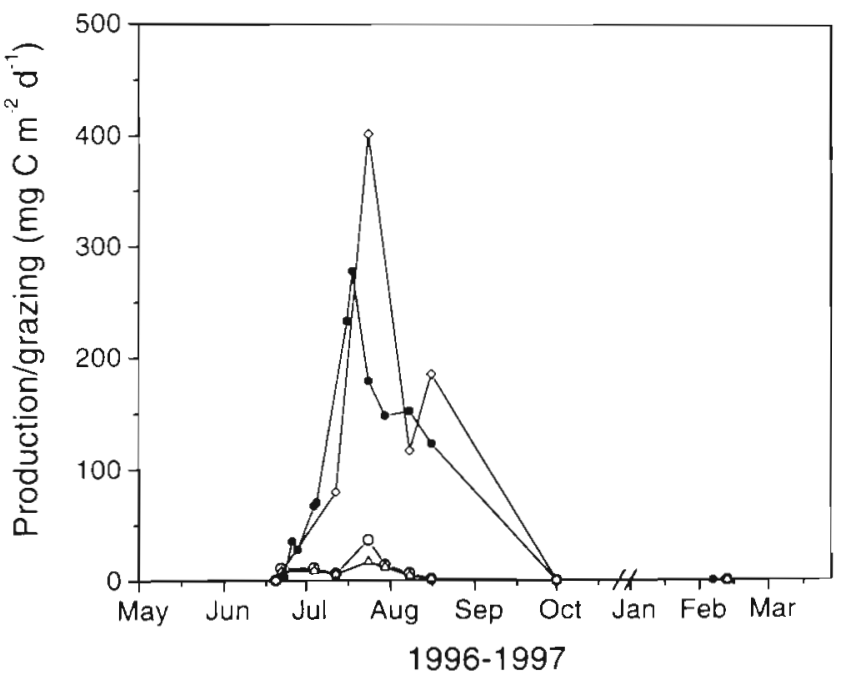

Fig. 7. Annual pelagic primary production $(\bullet)$ and grazing by ciliates $(0)$, heterotrophic dinoflagellates $(\Delta)$, and copepods $\left(0_{i}\right.$ estimated by Model 1, Huntley \& Lopez 1992)

cover in July presumably originated from algae released from the sea ice and/or from diatoms transported into the Sound from the Greenland Sea. It is known from the literature that sea ice algae released into the water column are not viable and cannot maintain a high primary production (Horner \& Scrader 1982) because of intolerance to low salinity water (Horner 1985). Thus, we assume that pelagic primary production was negligible within Young Sound before our investigation began. When our investigation ended in mid-August, pelagic primary production was declining because phytoplankton was limited by nutrients and grazed, primarily by mesozooplankton. Assuming that this decline continued until sea ice was re-established ( $>30 \mathrm{~cm}+$ snow cover) in early October, integration of the resulting curve for pelagic primary production provides an annual estimate of $10.3 \mathrm{~g} \mathrm{C} \mathrm{m}^{-2} \mathrm{yr}^{-1}$ (Fig. 7). A similar bell-shaped decline of polar primary production has been reported from various investigations (Steeman-Nielsen 1958, Petersen 1964, Grainger 1979, Smidt 1979, Smith \& Sakshaug 1990).

To our knowledge, only 1 other estimate of pelagic primary production based on annual measurements exists from the east coast of Greenland (Smith et al. 1997). Based on ${ }^{15} \mathrm{~N}$ techniques, and a converting factor using observed $\mathrm{C} / \mathrm{N}$ ratios, annual pelagic primary production was estimated at 0.25 to $0.36 \mathrm{~g} \mathrm{C} \mathrm{m}^{-2} \mathrm{~d}^{-1}$. Over a growth season, reported to be $2.7 \mathrm{mo}$, this amounts to an annual pelagic primary production of 18.8 to $27.0 \mathrm{~g} \mathrm{C} \mathrm{m}^{-2}$. This value represents a maximum estimate, however, since the normal bell-shaped production curve is not taken into account. The actual value may be lower, and thus comparable with measurements from Young Sound $\left(10.3 \mathrm{~g} \mathrm{C} \mathrm{m}^{-2} \mathrm{yr}^{-1}\right)$. Fur- 

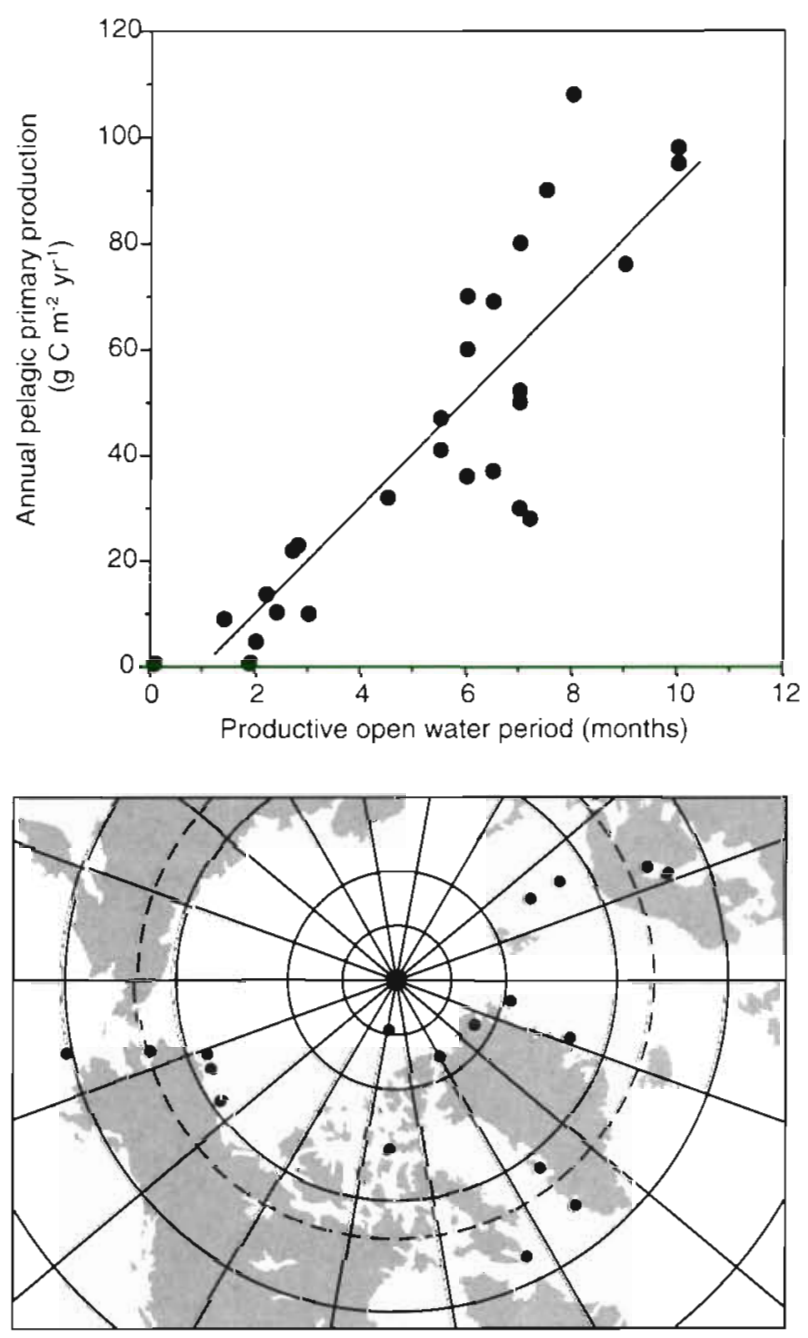

Fig. 8. (a) Annual pelagic primary production versus length of productive open water period. (b) Geographical location of investigations (Data compiled from: Steeman-Nielsen 1958, English 1961, Petersen 1964, Taguchi 1972, Alexander 1974, Welch \& Kalff 1975, McRoy \& Goering 1976, Meskus 1976 , Andersen 1977a, Carey 1978, Grainger 1979, Apollonio 1980, Andersen 1981, Horner \& Scrader 1982, Rey et al. 1987, Walsh et al. 1989, Slagstad \& Støle-Hansen 1991, Kangas et al. 1993,

Smith et al. 1997, Nielsen \& Hansen 1998, present study)

thermore, integrated water column primary production in our study is comparable with $1 \mathrm{~d}$ measurements made during July and August at several locations in the Northeast Greenland Water Polynya (Hirche et al. 1991, Smith 1995).

The annual pelagic primary production of $10.3 \mathrm{~g} \mathrm{C}$ $\mathrm{m}^{-2} \mathrm{yr}^{-1}$ in Young Sound is comparable with values from Jørgen Brønlund Fjord, North Greenland (4.7 to $13.7 \mathrm{~g} \mathrm{C} \mathrm{m}^{-2} \mathrm{yr}^{-1}$ ) (Andersen 1977a). As in Young Sound the productive open water period in Jørgen Brønlund Fjord is short (approx. 2 mo). The annual pelagic primary production found in these northern fjords and in the Northeast Water Polynya is lower than estimates from the southwest coast of Greenland. An annual pelagic primary production of $95 \mathrm{~g} \mathrm{C} \mathrm{m}^{-2} \mathrm{yr}^{-1}$ has been reported from Godthåb Fjord (SteemanNielsen 1958) and of 36 to $104 \mathrm{~g} \mathrm{C} \mathrm{m}^{-2} \mathrm{yr}^{-1}$ from Disko Bay (Petersen 1964, Andersen 1977b, 1981, Nielsen \& Hansen 1998). The difference in primary production between East and West Greenland is presumably due to the growth season being longer on the west coast, which, in turn, is due to the reduced sea ice cover and consequently the longer open water period generated by the relatively warm Irminger Current.

Compared with high-Arctic areas other than Greenland, the annual pelagic primary production in Young Sound resembles rates reported from Beauford Sea (5 to $10 \mathrm{~g} \mathrm{C} \mathrm{m}^{-2} \mathrm{yr}^{-1}$, Alexander 1974); the East Canadian Arctic (10 to $15 \mathrm{~g} \mathrm{C} \mathrm{m}^{-2} \mathrm{ys}^{-1}$, Harrison et al. 1982); and off Alaska ( 10 to $15 \mathrm{~g} \mathrm{C} \mathrm{m}^{-2} \mathrm{yr}^{-1}$, Alexander et al. 1975), but exceeds the annual production estimated in the central North Polar Sea (0.6 $\mathrm{g} \mathrm{C} \mathrm{m}^{-2} \mathrm{yr}^{-1}$, English 1961).

Data from the literature on annual primary production in Arctic waters was compiled, and the results plotted against the length of the productive open water period in the year of measurement (Fig. 8). The productive open water period was defined as the interval between the time of year when sea ice cover broke and the time of year when sea ice was established. Furthermore, only the period when light was present during the open water period was used in the compilation. In cases where sea ice data were not included in the papers, the relevant information was obtained either by personal communication with the author or from sea ice maps covering the site and period of the investigation in question. Finally, each data point in the figure represents an integration of several individual measurements (up to 24) of primary production throughout the productive period. A linear relationship between annual pelagic primary production and the length of the open water period was determined $\left(\mathrm{r}^{2}=0.76\right)$. The annual pelagic primary production in upwelling areas such as the Bering Strait (Sambrotto et al. 1984, Springer et al. 1996) is much higher (200 to $300 \mathrm{~g} \mathrm{C} \mathrm{m}^{-2}$ ) and not included in this plot, since these values are obviously out of range and cannot be described by this simple relationship. However, the good correlation indicates that on average the area-integrated pelagic primary production for a wide range of Arctic areas lies within the same range and that the length of the productive open water period therefore determines the amount of annual pelagic primary production.

Since a global increase in temperature, as observed over the past 100 yr (Hansen \& Lebedeff 1988), is expected to cause dramatic reduction and thinning of Arctic sea ice in summer (Manabe et al. 1992, Barry et 
a1. 1993), the linear relationship between annual pelagic primary production and open water period leads one to expect that the annual pelagic primary production within Arctic waters will be expected to increase as long as global warming continues. Furthermore, studies of detailed satellite records have indicated a shortening of the sea ice season, especially in the Sea of Okhotsk, the eastern Arctic Ocean, the Barents Sea, and off the north coast of Russia and the east coast of Greenland (Gloersen \& Campbell 1991, Gloersen et al. 1992, Parkinson 1992), and future alterations in annual pelagic primary production may be visible first within these areas.

Compared to the number of investigations on annual pelagic primary production, investigations on the annual production of sea ice algae are scarce. However, sea ice algae are prolific during the early spring, before the sea ice breaks up, and may contribute a considerable fraction of total primary production (Horner $\&$ Scrader 1982). If global warming reduces the sea ice cover in the future, it may be expected that the primary production of sea ice algae will be negatively affected in contrast to pelagic primary production. In order to determine the possible impact of alterations in sea ice cover on total primary production in Arctic areas, more studies of the relative contribution of sea ice algae to total primary production are required.

\section{Annual grazing by zooplankton}

The annual estimate of protozooplankton grazing on phytoplankton was based upon protozooplankton data obtained on 7 occasions during the productive open water situation and 1 sampling during winter. The same procedure as for phytoplankton was applied in the annual estimate of protozooplankton grazing. Thus, the integrated annual grazing on phytoplankton of ciliates and heterotrophic dinoflagellates was estimated at 0.8 and $0.6 \mathrm{~g} \mathrm{C} \mathrm{m}^{-2} \mathrm{yr}^{-1}$, respectively, representing $14 \%$ of annual primary production (Fig. 7 ).

For the copepods, only 4 measurements of biomass and calculated grazing values were available. We assumed that the calculated community grazing obtained for these 4 dates reflected the activity during the open water period. For further estimates of their annual productivity we assumed a productive season similar to that of phytoplankton. This assumption is supported by observations of copepod biomass at the same time of year in Scoresby Sound, $500 \mathrm{~km}$ further south (Digby 1953). As in Young Sound, the open water season in Scoresby Sound is restricted to approximately 2 mo. According to Digby, the copepod biomass increased from insignificant levels and reached $>200 \mathrm{mg} \mathrm{C} \mathrm{m}^{-3}$ in 3 distinct peaks between
June and August, with a mean (50 to $60 \mathrm{mg} \mathrm{C} \mathrm{m}^{-3}$ ) comparable to that found in the present study, and declined to low values by the end of September. Thus, assuming that a similar decline in biomass occurred in Young Sound the total annual grazing impact from copepods would amount to $10.8 \mathrm{~g} \mathrm{C} \mathrm{m}^{-2} \mathrm{yr}^{-1}$ according to Model 1 and $8.7 \mathrm{~g} \mathrm{C} \mathrm{m}^{-2} \mathrm{yr}^{-1}$ according to Model 2, representing 85 to $104 \%$ of the annual primary production (Fig. 7). Thus, a very tight and effective coupling between pelagic primary production and secondary production exists in Young Sound.

The future alterations in the amount of annual pelagic primary production expected in connection with global warming will markedly affect pelagic secondary production. It has been shown that, following a phytoplankton bloom associated with stratification of the water column, the growth rates of pelagic secondary producers normally become food limited (Kiørboe \& Nielsen 1994). Thus, prolonged ice-free periods and ensuing high rates of pelagic primary production are expected to lengthen the growth season of secondary producers and thereby increase the production and abundance of secondary producers in Arctic waters. However, studies have shown that copepods are able to exploit sea ice algae (e.g. Runge \& Ingram 1988), and, based on our preliminary results, it is believed that the main grazers on sea ice algae are the protozooplankton (Grastrup-Hansen unpubl.). The importance of this energetic pathway, and consequently the effect of changes in ice cover on secondary production, has still not been investigated thoroughly and needs further attention in the future.

Acknowledgements. This study was financially supported by the Danish Research Councils (contract no. 9501025 and 9700224, S.R.; contract no. 95010038 , B.W.H. and T.G.N.). Nils Risgaard-Petersen, Tage DaIsgaard, Peter Bondo Christensen and Egon Frandsen are thanked for field assistance. Finally, Anna Haxen is acknowledged for linguistic corrections.

\section{LITERATURE CITED}

Alexander V (1974) Primary productivity regimes of the nearshore Beaufort Sea, with reference to potential roles of ice biota. In: Reed J, Sater J (eds) The coast and shelf of the Beaufort Sea. Proceedings of a symposium of Beauford Sea coast and shelf research. Arctic Inst of North America, Washington, DC, p 609-632

Alexander V, Burell DC, Chang J, Cooney RT, Coulon C, Crane JJ, Dygas JA, Hall GE, Kinney PJ, Kogl D, Mowat TC, Naidu AS, Osterkamp TE, Siefert RD, Tucker RW (1975) Environmental studies of an Arctic estuarine system-final report. US Environ Protect Agency ORD Ecol Res Ser. US EPA, Washington, DC

Andersen OGN (1977b) Primary production associated with sea ice at Godhavn, Disko, West Greenland. Ophelia 16:205-220

Andersen OGN (1977a) Primary production, illumination and hydrography in Jørgen Brønlund Fjord, North Greenland. Medd Gronl 205:1-27 
Andersen OGN (1981) The annual cycle of phytoplankton primary production and hydrography in the Disko Bugt area. West Greenland. Medd Gronl Biosci 6:3-65

Apollonio S (1980) Primary production in Dumbell Bay in the Arctic Ocean. Mar Biol 61:41-51

Ashjian CJ, Smith S, Lane PVZ (1995) The Northeast water polynya during 1992: distribution and aspects of secondary production of copepods. J Geophys Res 100:4371-4388

Barry RG, Serreze MC, Maslanik JA (1993) The Arctic sea ice-climate system: observations and modeling. Rev Geophys $31: 397-422$

Bower C, Holm-Hansen I (1980) A salicylate-hypochlorite method for determining ammonia in seawater. Can J Fish Aquat Sci 37:794-798

Carey AG (1978) Marine biota. In: Environmental Assessment Alaskan Continental Shelf Interim synthesis: Beaufort/ Chukchi. NOAA, Boulder, CO, p 174-237

Daly KL (1997) Flux of particulate matter through copepods in the Northeast Water Polynya. J Mar Syst 10:319-342

Digby PSB (1953) Plankton production in Scoresby Sound, East Greenland. J Anim Ecol 22:289-322

Dodge JD (1985) Marine dinoflagellates of the British Isles Her Majesty's Stationary Office, London

Edler L (1979) Recommendations for marine biological studies in the Baltic Sea. Publ Baltic Mar Biol 5:1-38

Egge JK, Aksnes DL (1992) Silicate as regulating nutrient in phytoplankton competition. Mar Ecol Prog Ser 83:281-289

English TS (1961) Some biological oceanographic observations in the central north Polar Sea drift station Alpha, 1957-1958. Arct Inst N Am Tech Pap 13:viij-80

Gloersen P. Campbell WJ (1991) Recent variations in Arctic and Antarctic sea ice covers. Nature 352:33-36

Gloersen P, Campbell WJ, Cavalieri DJ, Comiso JC, Parkinson CL, Zwally HJ (1992) Arctic and Antarctic sea ice, 1978-1987: satellite passive microwave observations and analysis. NASA, Washington, DC

Grasshoff K, Erhardt M, Kremling K (1983) Methods of seawater analysis, 2 nd revised and extended version. Verlag Chemie, Weinheim

Grainger EH (1979) Primary production in Frobisher Bay. Arctic Canada. In: Dunbar MJ (ed) Marine production mechanisms. Cambridge University Press, Cambridge, p 9-30

Hansen B. Christiansen S, Pedersen G (1996) Planktonic dynamics in the marginal ice zone of the central Barents Sea during spring: carbon flow and structure of the grazer food chain. Polar Biol 16:115-128

Hansen B, Bjornsen PK, Hansen PJ (1994) The size ratio between planktonic predators and their prey. Limnol Oceanogr 39:395-403

Hansen J, Lebedeff S (1988) Global surface air temperatures: update through 1987. Geophys Res Lett 15:323-326

Hansen J, Fung I, Lacis A, Rind D, Lebedeff S, Ruedy R, Russell $G$ (1988) Global climate changes as forecast by Goddard Institute for Space Studies' three-dimensional model. J Geophys Res 93:9341-9364

Hansen PJ, Bjørnsen PK, Hansen BW (1997) Zooplankton grazing and growth: scaling within the $2-2.000 \mu \mathrm{m}$ body size range. Limnol Oceanogr 42:687-704

Harrison WG, Cota GF (1991) Primary production in polar waters: relation to nutrient availability. In: Sakshaug $E$, Hopkins CCE, Øritsland NA (eds) Proceedings of the Pro Mare Symposium on Polar Marine Ecology, Tronheim. Polar Res 10(1):87-104

Harrison WG, Platt T, Irwin B (1982) Primary production and nutrient assimilation by natural phytoplankton populations of the eastern Canadian Arctic. Can J Fish Aquat Sci $39: 335-345$
Hirche HJ, Bohrer RN (1987) Reproduction of the Arctic copepod Calanus glacialis in Fram Strait. Mar Biol 94:11-17

Hirche HJ, Baumann MEM, Kattner G, Gradinger R (1991) Plankton distribution and the impact of copepod grazing on primary production in Fram Strait, Greenland Sea. J Mar Syst 2:477-494

Hirche HJ, Hagen W, Mumm N, Richter C (1994) The North east water polynya, Greenland Sea. III. Meso- and macrozooplankton distribution and production of dominant herbivorous copepods during spring. Polar Biol 14:491-503

Horner RA (1985) Sea ice biota. CRC Press, Inc, Boca Raton, FL

Horner RA, Scrader GC (1982) Relative contributions of ice algae, phytoplankton and benthic microalgae to primary production in nearshore regions of the Beaufort Sea. Arctic 35:485-503

Huntley ME, Lopez MDG (1992) Temperature-dependent production of marine copepods: a global synthesis. Am Nat 140:201-242

Jespersen AM, Christoffersen K (1987) Measurements of chlorophyll-a from phytoplankton using ethanol as extraction solvent. Arch Hydrobiol 109:445-454

Kangas P, Alsaarela E, Lax HG, Jokela S, Storegård-Envall C (1993) Seasonal variation of primary production and nutrient concentrations in the coastal waters of the Bothnian Bay and the Quark. Aqua Fenn 23:165-176

Kiørboe T, Nielsen TG (1994) Regulation of zooplankton biomass and production in a temperate, coastal ecosystem. 1. Copepods. Limnol Oceanogr 39:493-507

Krainer K, Foissner (1990) Revision of the genius Askenasia Blochmann, 1985, with proposal of two new species, and description of Rhabdoaskenasia minima n.g., n.sp. (Ciliophora, Cyclotrichida). J Protozool 37:414-427

Lara R, Kattner G, Tillmann U, Hirche HJ (1994) The North east water polynya (Greenland Sea). II. Mechanisms of nutrient supply and influence on phytoplankton distribution. Polar Biol 14:483-490

Levinsen H, Nielsen TG, Hansen BW (1998) Plankton community structure and carbon cycling on the western coast of Greenland during the stratified summer situation. II. Heterotrophic dinoflagellates and ciliates. Aquat Microb Ecol 16:217-232

Lynn DJ, Montagnes JS, Small EB (1988) Taxonomic descriptions of some conspicuous species in the family Strombidiidae (Chiliophora: Oligotrichida) from the Isles of Shoals, Gulf of Maine. J Mar Biol Assoc UK 68:259-276

Manabe S, Stouffer RJ (1994) Multi-century response of a coupled ocean-atmosphere model to an increase of atmospheric carbon dioxide. J Clim 7:5-23

Manabe S, Spelman MJ, Stouffer RJ (1992) Transient responses of a coupled ocean-atmosphere model to gradual changes of atmospheric $\mathrm{CO}_{2}$. II. Seasonal response. J Clim $5: 105-126$

McRoy CP, Goering J (1976) Annual budget of primary production in the Bering Sea. Mar Sci Commun 2:255-267

Meskus E (1976) The primary production of phytoplankton in the northeastern Bothnian Bay. Acta Univ Ouluensis Ser A Sci Rerum Nat 42(3):55-62

Nielsen TG, Hansen BW (1995) Plankton community structure and carbon cycling on the Arctic coast of western Greenland during and after the sedimentation of a diatom bloom. Mar Ecol Prog Ser 125:239-257

Nielsen TG, Hansen BW (1998) Plankton community structure and carbon cycling on the western coast of Greenland during the stratified summer situation. I. Hydrography, phytoplankton and bacterioplankton. Aquat Microb Ecol $16: 205-216$ 
Parkinson (1992) Spatial patterns of increases and decreases in the length of the sea ice season in the North Pole Region 1979-1986. J Geophys Res 97:14377-14388

Petersen GH (1964) The hydrography, primary production. bathymetry, and 'Tagsáq' of Disko Bugt, West Greenland. Medd Gronl 159:1-45

Peterson WT (1988) Rates of egg production by the copepod Calanus marshallae in the laboratory and the sea off Oregon. Mar Ecol Prog Ser 47:229-237

Rao DVS, Platt T (1984) Primary production of Arctic waters Polar Biol 3:191-201

Rey F, Skjoldal HR, Slagstad D (1987) Primary production in relation to climatic changes in the Barents Sea. In: Loeng $\mathrm{H}$ (ed) The effect of oceanographic conditions on distribution and population dynamics of commercial fish stocks in the Barents Sea. Proc 3rd Soviet-Norwegian Symp. Murmask, 26-28 May 1986. Institute of Marine Research, Bergen, p 29-46

Runge JA (1985) Egg production rates of Calanus finmarchicus in the sea off Nova Scotia. Arch Hydrobiol 21 $33-40$

Runge JA, Ingram RG (1988) Under ice grazing by planktonic, calanoid copepods in relation to a bloom of icealgae in southeastern Hudson Bay. Limnol Oceanogr 33 $280-286$

Rysgaard S, Finster K, Dahlgaard H (1996) Primary production, nutrient dynamics and mineralization in a northeastern Greenland fjord during the summer thaw. Polar Biol 16:497-506

Rysgaard S, Thamdrup B, Risgaard-Petersen N, Fossing $\mathrm{H}$ Berg P, Christensen PB, Dalsgaard T (1998) Seasonal carbon and nutrient mineralization in a high-Arctic coastal marine sediment, Young Sound, Northeast Greenland Mar Ecol Prog Ser 175:261-276

Sambrotto RN, Goering JJ, McRoy CP (1984) Large yearly production of phytoplankton in the western Bering Strait Science 325:1147-1150

Slagstad D, Støle-Hansen K (1991) Dynamics of plankton growth in the Barents Sea: model studies. Polar Res 10:173-186

Slagstad D, Wassmann P (1995) Climatic change and carbon flux in the Barents Sea: 3-D simulation of ice-distribution, primary production and vertical export of particulate organic carbon. In: Proceedings of the International Symposium on Environmental Research in the Arctic, 19-21 July, Tokyo, Japan, Vol 51 National Institute of Polar Research, Tokyo, p 119-141

Smidt ELB (1979) Annual cycles of primary production and of zooplankton at Southwest Greenland. Medd Gronl Biosci $1: 3-53$

Smith SL, Smith WO, Codispoti LA, Wilson DL (1985) Biological observations in the marginal ice zone of the East Greenland Sea. J Mar Res 43:693-717

Editorial responsibility: Otto Kinne (Editor),

Oldendorf/Luhe, Germany
Smith WO Jr (1995) Primary productivity and new production in the Northeast Water (Greenland) Polynya during summer 1992. J Geophys Res 100:4357-4370

Smith WO Jr, Sakshaug E (1990) Polar phytoplankton. In: Polar oceanography, Part B. Chemistry, biology and geology. Academic Press, New York, p 477-525

Smith W Jr, Gosselin M, Legendre L, Wallace D, Daly K, Kattner G (1997) New production in the Northeast Water Polynya: 1993. J Mar Syst 10:199-209

Spies A, Brockmann UW, Kattner G (1988) Nutrient regimes in the marginal ice zone of the Greenland Sea in summer. Mar Ecol Prog Ser 47:195-204

Springer AM, McRoy P, Flint MV (1996) The Bering Sea green belt: shelf-edge processes and ecosystem production. Fish Oceanogr 5:205-223

Steeman-Nielsen E (1952) The use of radio-active carbon (C14) for measuring organic production in the sea. J Cons Perm Int Explor Mer 18:117-140

Steeman-Nielsen E (1958) A survey of recent Danish measurements of the organic productivity in the sea. J Cons Perm Int Explor Mer 144:92-95

Strickland JDH, Parsons TR (1972) A practical handbook of sea water analysis. Bull Fish Res Board Can 167:1-310

Taguchi S (1972) Mathematical analysis of primary production in the Bering Sea in summer. In: Takenouti AY (ed) Biological oceanography of the northern North Pacific Ocean. Idemitsu Shoten, Tokyo, p 253-262

Thomsen HA (1992) Plankton in Danish waters. The marine research programme, No. 11 The Danish Agency of Environmental Protection, Copenhagen (in Danish with an English summary)

Ütermöhl H (1958) Zur Vervollkommung der quantitativen Phytoplankton-Methodik. Mitt Int Ver Theor Angew Limnol 9:39

Vadstein O, Harkjeer BO, Jensen A (1989) Cycling of organic carbon in the photic zone of a eutrophic lake with special reference to the heterotrophic bacteria. Limnol Oceanogr 34:840-855

Walsh JJ, McRoy CP, Coachman LK, Goering JJ, Nihoul JJ, Whitledge TE, Blackburn TH, Parker PL, Wirick CD, Shuert PG, Grebmeier JM, Springer AM, Tripp RD, Hansell PG, Djenidi S, Deleersnijder E, Henriksen K, Lund BA, Andersen P, Müller-Karger FE, Dean K (1989) Carbon and nitrogen cycling within the Bering/Chuckchi Seas: source regions for organic matter effecting $A O U$ demands of the Arctic Ocean. Prog Oceanogr 22:277-359

Welch HE, Kalff J (1975) Marine metabolism at Resolute Bay, Northwest Territories. In: Proc Circumpolar Conf Northern Ecol Part II. NRC Canada, Ottawa, p 67-75

Weslawski J, Wiktor MJ, Koszeteyn J, Zajaczkowski M, Wieczorek P. Kotwicki L (1997) The coastal edge of the Northeast Water Polynya in spring 1993. J Mar Syst 10:429-444

Submitted: May 11, 1998; Accepted: November 3, 1998

Proofs received from author(s): March 24, 1999 